\title{
New Aspects in Immunopathology of Mycobacterium tuberculosis
}

\author{
E. Mortaz,,${ }^{1,2}$ M. Varahram, ${ }^{3}$ P. Farnia, ${ }^{3}$ M. Bahadori, ${ }^{1}$ and MR Masjedi ${ }^{1}$ \\ ${ }^{1}$ Chronic Respiratory Disease Research Center, National Research Institute of Tuberculosis and Lung Disease (NRITLD), \\ Masih Daneshvari Hospital, Shahid Beheshti University of Medical Sciences, Tehran, Iran \\ ${ }^{2}$ Division of Pharmacology and Pathophysiology, Utrecht Institute for Pharmaceutical Sciences, Faculty of Sciences, \\ Utrecht University, Utrecht, The Netherlands \\ ${ }^{3}$ Mycobacteriology Research Centre, National Research Institute of Tuberculosis and Lung Disease, Shahid Beheshti University, \\ Tehran, Iran
}

Correspondence should be addressed to MR Masjedi, mrmasjedi@gmail.com

Received 4 January 2012; Accepted 24 January 2012

Academic Editor: L. Szereday

Copyright (C) 2012 E. Mortaz et al. This is an open access article distributed under the Creative Commons Attribution License, which permits unrestricted use, distribution, and reproduction in any medium, provided the original work is properly cited.

\begin{abstract}
Our understanding of tuberculosis (TB) pathology and immunology has become extensively deeper and more refined since the identification of Mycobacterium tuberculosis (MTB) as the etiologic agent of disease by Dr. Robert Koch in 1882. A great challenge in chronic disease is to understand the complexities, mechanisms, and consequences of host interactions with pathogens. TB, caused by MTB, is a major health problem in world, with 10 million new cases diagnosed each year. Innate immunity is shown playing an important role in the host defense against the MTB, and the first step in this process is recognition of MTB by cells of the innate immune system. Several classes of pattern recognition receptors (PPRs) are involved in the recognition of MTB, including toll-like receptors (TLRs), C-type lectin receptors (CLRs), and nod-like receptors (NLRs). Among the TLR family, TLR1, TLR2, TLR4, and TLR9 and their down streams, proteins play the most prominent roles in the initiation of the immune response against MTB. Beside of TLRs signaling, recently the activation of inflammasome pathway in the pathogenesis of TB much appreciated. Knowledge about these signaling pathways is crucial for understanding the pathophysiology of TB, on one hand, and for the development of novel strategies of vaccination and treatment such as immunotherapy on the other. Given the critical role of TLRs/inflammasome signaling in innate immunity and initiation of the appropriate adaptive response, the regulation of these pathways is likely to be an important determinant of the clinical outcome of MTB infection. In this review paper we focused on the immune response, which is the recognition of MTB by inflammatory innate immune cells following infection.
\end{abstract}

\section{Introduction}

Despite the availability of effective and inexpensive therapy, $\mathrm{TB}$ is considered as one of the leading causes of death from an infectious disease worldwide [1].

For long time it is believed that $\mathrm{TB}$ is a major public health problem in the world, with 10 million new cases diagnosed each year, causing a death toll of 2 million victims. However, from the estimated 2 billion individuals that have been initially infected with mycobacterium tuberculosis (MBT), only $5 \%$ to $10 \%$ develop symptomatic TB $[2,3]$. The reason of the susceptibility of individual to the $\mathrm{TB}$ is not well described. The role of inborn variability in susceptibility to TB has been described [4]. This finding indicates that at least some individuals display an effective immune response against the MTB and that this plays an important part in determining the disease [5].

In addition, this episode in young infants known to have immature adaptive immunity also suggests that the innate host defense is an important arm of antimycobacterial host defense [6]. Thus, understanding the immunologic pathway and mechanism leading to inflammatory process by MTB may lead to better therapeutic approaches in controlling the TB. In this review paper we will cover the role of immune cells and inflammatory mediators which might be playing role in the pathogenesis of TB. We will also outline the role of both Th1 and IL-17 response against TB. Finally, we will discuss the ability of MBT to activate innate immunity such 
as toll-like receptors (TLRs) or inflammasome pathways and how these receptors contribute to inflammation by signal transduction pathways.

\section{Immunology of MTB}

The human immune response to $\mathrm{TB}$ is a complex reaction to infection with a vigorous pathogen. This interaction between cellular immune system takes place in a fluid environment containing a wide variety of inflammatory mediators, and these various factors have a large impact on the body's ability to successfully contain infection. In the last few years in vitro and animal studies have begun to be complemented by human studies using material obtained by BALfrom TB patients and from control volunteers.

Here, we tried to summarize the information available on host immune response to the TB, complexity of hostpathogen interaction and highlight the importance of signal transduction mechanisms involved in the pathogenesis of TB.

In these regards emerging data emphasizes that the host defenses against MTB need an immune cellular response usually via activation of Th1/Th17 [7, 8]. For long time it has been shown that $\mathrm{T}$-cell subsets based on immune responses have been the delineation of the T helper 1/T helper 2 which provides a framework for understanding how the immune system directs responses to the diversity of pathogens and stimuli. The two major subsets of CD4 T-helper cells, Th1 and Th2, have different patterns of mediators production, playing different roles in immune responses.

Th1 is characterized by TNF- $\alpha$, IL-2, INF- $\gamma$ production, and Th2 cells by IL-4, IL-5, and IL-13 release. Th1type cytokines stimulate macrophages and cell-mediated reactions (CMRs) important in resistance to infection with intracellular pathogens, and in cytotoxic and delayed-type hypersensitivity (DTH) reactions. Th2 cells release IL-4, IL-5, IL-6, IL-10, and IL-13; Th2-type cytokines encourage diverse antibody production and are, therefore, commonly found in association with antibody responses that are important in combating infections with extracellular organisms [9]. Th1 and Th2 cells are mutually inhibitory to each other; IL-10, a product of Th2 cells, inhibits the development of Th1 cells by acting on antigen-presenting cells, whereas IFN- $\gamma$, a product of Th1 cells, prevents the activation of Th2 cells $[10,11]$.

In this line it has been demonstrated that defects in the generation of the Th1 cell effector INF- $\gamma$ resulted in susceptibility to TB infection $[12,13]$. MTB initially infects inflammatory cells especially macrophages and dendritics cells [14]. MTB is surrounded by a lipid-rich outer molecules as a capsule which protects it from the toxic radicals and hydrolytic enzymes produced as a defense by macrophages and inflammatory cells [15]. Pathogenic mycobacteria can spread into neighboring resting macrophages and other cells considered for replication. Macrophages, activated by exposure to inhaled particulates, possess potent microbicidal activity which can kill bacilli and arrest $\mathrm{TB}$ infection, but usually they cannot eliminate infection entirely [16]. Other critical mechanisms of antimycobacterial immunity include the destruction of infected cells by cytolytic T lymphocytes has been documented $[17,18]$.

While $\mathrm{CD} 4^{+} \mathrm{T}$ cells are generally acknowledged to be crucial, the contribution of other T-cell subsets including gamma/delta $\mathrm{T}(\gamma \delta \mathrm{T})$ cells, Th17 cells, and even conventional $\mathrm{CD} 8^{+} \mathrm{T}$ cells has been described by many investigators [19-21]. In this line an initial growth of MTB results in a delayed type hypersensitivity response which is characterized by the formation of small necrotic lesions with solid caseous centers in infected area [22]. MTB multiplication is shown that restricted while encapsulated in these granulomatus lesions. Granulomas (lesions) consist of T lymphocytes and mononuclear phagocytes of various levels of maturation and stimulation [23]. After starting delayed-type hypersensitivity (DTH) and tubercle formation, stimulation of macrophages by $\mathrm{CD} 4^{+} \mathrm{T}_{\mathrm{DTH}}$ cells enables the macrophages to kill bacilli inside of the tubercle lesions. Macrophage activation appears to be a central step of acquired resistance against MTB [24].

Macrophage activation is achieved by $\mathrm{T}$ lymphocytes which are the principle mediator of cell-mediated immune response against MTB. $\mathrm{CD}^{+} \mathrm{T}$ cells are primarily helper $\mathrm{T}$ cells which secrete different types of interleukins involved in the activation of macrophages [25]. In the DTH response to $\mathrm{MTB}, \mathrm{CD}^{+} \mathrm{T}$ cells predominate over $\mathrm{CD}^{+} \mathrm{T}$ cells which are primarily cytolytic cells that lyse specific target cells. Helper T cells are required to recruit and activate new monocytes and macrophages to the tubercle lesions. As indicated earlier, Th1 cells produce the cytokines IFN- $\gamma$ and IL-2, which are important for activation of antimycobacterial activities and essential for the DTH response. IFN- $\gamma$ specifically activates macrophages and stimulates them to ingest and kill mycobacteria more effectively [26]. Macrophage activation by cytokines provides only a partial explanation for immunity to MTB. The presence of an MHC Class I-restricted response to mycobacterial infection has been described in several $\mathrm{T}$ lymphocytes. $\mathrm{CD}^{+} \mathrm{T}$ lymphocytes contribute to macrophage activation by producing IFN- $\gamma$ [26]. $\mathrm{CD}^{+} \mathrm{T}$ cells also may have capability as a cytolytic functions which enable them to recognize mycobacterial antigens presented by MHC Class I molecules on the surface of infected macrophages. $\mathrm{CD} 8^{+}$cytotoxic $\mathrm{T}$ lymphocytes (CTLs) are thought to be required to release intracellular MTB residing in infected macrophages [27]. CTLs with specificity for MTB antigens have been identified in the murine model of tuberculosis. In this line it has been shown that exogenous antigen can gain access to Class I processing and presentation pathway and elicit a $\mathrm{CD}^{+} \mathrm{T}$-cell response in vivo.

Besides, it has been demonstrated that MTB has the ability to survive within macrophages, providing metabolic antigens for processing and presentation with Class I molecules on the macrophage surface [26]. It has been suggested that MTB may be able to avoid processing within the phagolysosomal environment and in doing so antigen may enter the endogenous antigen-processing pathway and be presented to $\mathrm{CD}^{+} \mathrm{T}$ cells [28].

Thus, now it has been proposed that $\mathrm{CD}^{+} \mathrm{T}$ cells may also play a role in host defense against MTB infection via cytolytic activity [29]. In this regard, $\mathrm{CD}^{+} \mathrm{T}$ cells may also 
be capable of lysing nonactivated, infected macrophages and subsequently be taken up by activated macrophages which can destroy the mycobacteria. The presence of $\mathrm{CD}^{+} \mathrm{T}$ cells has been detected only in vitro human peripheral blood samples [30].

Gamma/delta $(\gamma \delta) \mathrm{T}$ cells have been shown playing an important role in host defence against MTB. In particular, these cells can lyse macrophages containing mycobacteria and are an early source of IFN- $\gamma$ [31]. They might have a role in the initial, innate immune response to MTB, because their population is expanded by mycobacteria and mycobacterial products in tissues. Interestingly, it has been shown that after subcutaneous and aerosol immunization of mice with mycobacteria, a significant proportion of the mycobacteriareactive gamma/delta $\mathrm{T}$ cell population was activated [32]. These cells are also able to release IFN- $\gamma$ which may be an important trigger at initial stages of immune response against TB.

Natural killer (NK) cells may also play an important role in the host immune response to MTB. NK cells shown are able of lysing host cells infected with MTB pathogens indicating functional similarities with specific cytolytic $\mathrm{T}$ lymphocytes [33, 34].

The role of $\mathrm{T}_{\text {reg }}$ cells in immunity to MTB has not yet described, however based on studies in humans have shown that numbers of $\mathrm{T}_{\text {regs }}$ are augmented in the blood and at infection sites in patients with active form of the TB [35-37].

Finally the role of Th17 cells and IL-23 recently has been emerged. For example, it has been shown that, by TB aerosol infection, the absence of IL-23 leads to ablation of the Th17 response and significant loss of IL-17mRNA expression in the lung [38]. These data demonstrate that IL-23 is essential to the expression of both the Th17 population and the IL17 response to the TB infection. Regardless of the specific role of IL-23, it is likely that this cytokine will be required for optimal Th17 responses to mycobacterial infection in humans. It has been shown that IL-17 is recognized as an inflammatory cytokine capable of inducing chemokine gradients and initiating inflammation, particularly in the lung [39-41]. IL-17 and IL-23 induced neutrophils influx and hemostasis into the lungs of MTB infected mice [42].

It is clear therefore that IL-23 and IL-17 are acting in a complex manner in the control of TB-induced inflammation. This is not so surprising as IL-17 can act as a mediator of macrophage accumulation [43] and mediated of induction of CXCL chemokines containing IL-17-associated promoter elements $[44,45]$.

Thus, these data suggest that during TB infection IL-17 can act to mediate accumulation of both polymorphic and mononuclear cells.

\subsection{Cellular Immunity to MTB}

2.1.1. Macrophages and Monocytes. Macrophages are important effector cells in immunity to intracellular bacteria but at the same time are exploited as host cells by a number of microorganisms such as MTB. Macrophage cell death is thought to play a major role in TB pathogenesis [46].
Macrophages are important effector cells in immunity to intracellular bacteria but at the same time are exploited as host cells by a number of microorganisms such as MTB. As indicated earlier, MTB, the causative agent of TB, is a facultative intracellular parasite of macrophages. In order for MTB to establish infection, it must first entier into alveolar macrophages following the inhalation of infectious aerosols. Macrophages are able to engulf inhaled bacteria by using a variety of phagocytic receptors. A number of different phagocytic receptors have been implicated in MTB entry to macrophages such as complement toll-like and mannose receptors [47-49].

It has been reported that MTB infection is accompanied by nonspecific inflammatory responses regulated by inflammatory mediators produced by macrophages which are activated by various signals $[50,51]$ which is followed by delivering the bacteria to phagolysosomes as an important mechanism to remove intracellular pathogens. After phagocytosis, nonpathogenic MBT is degraded by the acidification of the phagosomal compartment that contains hydrolases active at low $\mathrm{pH}$. Keys to the virulence of MTB are its capacity to prevent the incorporation of the ATP/proton pump into the phagosome membrane and to restrict the fusion of this vacuole with lysosomes [52].

In this line it has been shown that, in resting macrophages, pathogenic MBT blocks phagosome maturation to assure intracellular survival and replication [53-55]. However, in activated macrophages by IFN- $\gamma$, the maturation of phagosome was blocked, possibly through induction of and intersection with the autophagic pathway. Within the phagolysosome, MTB is deprived of essential nutrients such as iron and exposed to microbicidal effectors generated by IFN- $\gamma$-activated macrophages such as antimicrobial peptides (AMPs) and reactive oxygen or nitrogen intermediates, the products of $\mathrm{NADPH}$ oxidase and nitric oxide synthase (NOS2), respectively [56-58]. Besides, it has been shown that macrophages may respond by undergoing TNF- $\alpha$-mediated apoptosis and possibly through other cell-death pathways $[59,60]$.

Apoptosis contributes to host defense by removing the MTB growth, by direct antimicrobial effects, and by packaging MTB bacilli and antigens in apoptotic bodies. The subsequent engulfment of these apoptotic bodies by newly recruited macrophages and DCs promotes the eradication of infection and the induction of the adaptive immune response [61].

2.1.2. Polymorphonuclear Cells (PMN). Neutrophils are the cells rapidly recruited to sites of MTB infection, where they phagocytose bacilli effectively [62]. In this line it has been shown that neutrophils are professional phagocytes cells that play important roles in many infections, and increased amounts of neutrophils are observed in the BAL fluid of patients with pulmonary MTB [63]. Moreover, animal studies have also described acute and chronic neutrophil accumulation during MTB infection [64, 65], which could be suggested to speculation on various roles for neutrophils in the development of TB [66]. Nevertheless, the exact 
role of neutrophils in the pathogenesis of MTB infection in humans is still not completely understood. There are few reports describing increased neutrophil populations and their phagocytic activity in patients with active pulmonary MBT [67].

2.1.3. Dendritic Cells Response. The critical role of DCs in the pathogenesis of MBT has been extensively described. In this regard, different subsets of DCs are most potent APCs of the innate immune system that have the ability to stimulate quiescent, naive, or memory $\mathrm{T}$ lymphocytes [68]. DCs exist at various stages of development, activation, and maturation that are defined by distinct phenotypic and functional modalities [69]. After inhalation, MTB is phagocytosed by alveolar macrophages and DCs resident in the alveolar space of lungs. It has shown that DCs are able to efficiently travel to local lymph nodes and successfully present antigen to $\mathrm{T}$ cells, which generates effective cellmediated immunity $[70,71]$. Translocation of MTB to the lymph node by infected DCs is an important precursor to T-cell activation $[72,73]$. Upon exposure of DCs to MTB, IL-12p70 and IL-23 are induced which are playing critical role in the pathogenesis of TB [74-76]. Besides, it has been shown that DCs undergo cell death after infection with MTB in vitro, just as macrophages, and could help by this way the protection of host against TB [77].

2.2. Humoral Immunity to MBT. As indicated earlier IFN$\gamma$, an inflammatory cytokine stimulates the antimicrobial activity of macrophages and regulates their antigen presentation through the MHC Class II molecules by upregulating their mRNA and protein expression [78]. As well, IFN- $\gamma$ can induce autophagy, a mechanism that plays an important role in the innate immunity against intracellular microorganisms $[79,80]$. MHC type II-restricted $\mathrm{CD}^{+} \mathrm{T}$ cells, MHC class I $\mathrm{CD}^{+} \mathrm{T}$ cells, and macrophages are important in the protective immunity against MTB where a decrease of the number or function of these cells results in the reactivation of the infection [81], and $\gamma / \delta \mathrm{T}$ cells play an important role in the protective immune response to tuberculosis (TB) [82].

MTB is an obligatory aerobic, intracellular pathogen, which has a predilection for the lung tissue rich in oxygen supply. The MTB enters the body via the respiratory system route. The bacilli spread from the site of initial infection in the lung through the lymphatics or blood circulation to the other parts of the body, the apex of the lung, and the regional lymph node being $[83,84]$.

Extrapulmonary TB of the pleura, lymphatics, bone, genitourinary system, meninges, peritoneum, or skin occurs in about 15 percent of TB patients $[85,86]$.

Immunity to MTB associated with Th1 activity involves TNF- $\alpha$, IFN- $\gamma$, and IL-12 releases. Neutralization of TNF- $\alpha$ leads to reactivation of disease [87] and genetic defects of the receptors for IFN- $\gamma$ or IL-12 lead to increased susceptibility to MTB (see Figure 1) [88].

Initiation of the innate immune response starts with pattern recognition of microbial structures called pathogenassociated molecular patterns (PAMPs). Recognition of
PAMPs is performed by germline-encoded receptors expressed mainly on immune cells termed pattern recognition receptors (PRRs).

The first step in understanding the mechanisms of recognition of pathogenic bacteria is a solid knowledge of the structure of the cell wall of the microorganism, which is the first structure to come in contact and to be recognized by the cells of the immune system. It has been demonstrated that dectin and TLR4 are playing role in induction of IL17 by TB [89]. The cytokine IL-10, which is generally secreted by $\mathrm{TH} 2$ cells, affects macrophages by suppressing cytokine production, and thereby downregulating TH1 cell activity and proliferation, and one study suggests that IL-10 plays a central role in enhancing the survival of MTB within macrophages [90]. It has been shown in a variety of studies that both cytolytic $\mathrm{T}$ lymphocytes and IFN- $\gamma$-activated macrophages are necessary for conferring protective immunity against MTB [91]. As a result these are the immunological pathways that must be focused on in developing an efficacious vaccine to tuberculosis. The Th1 pathway of the immune response including CTL activation is best stimulated by antigens that have been synthesized and degraded inside the cell and presented on the cell surface with MHC Class I. IFN- $\gamma$ is an important cytokine for immune protection, but, in excess, it is also a key mediator of immunopathology. Massive activation of macrophages within tubercles by IFN- $\gamma$ results in concentrated release of lytic enzymes. These enzymes destroy neighboring healthy cells and create circular regions of necrotic tissue [92].

\section{Role of Signal Transduction Pathways in the Pathogenesis of MBT}

3.1. Role of Toll-Like Receptors (TLRs) in Pathogenesis of $M T B$. Toll-like receptors (TLRs) play a critical role in both innate resistance and the initiation of adaptive immunity to infectious agents [93-96]. So far fifteen functional TLRs have been identified in mammals, and they are playing important role in specific recognition of pathogen associated molecules [97]. Upon ligand binding to the receptors, TLRs initiate a cascade of events leading to the transcription of NF- $\kappa \mathrm{B}$-dependent genes, mostly inflammatory genes. TLRs recognize pathogen-associated molecular patterns (PAMPs) or endogenous inflammation-associated molecules [98-100]. TLRs recognize distinct molecular structures on microbes, and, in several cases (e.g., recognition of viruses by TLR3, TLR7, TLR8, and TLR9), different sets of TLRs have been associated with the response to different classes of microorganisms [101-103]. PAMPs are for diverse microbially derived molecules expressed predominantly on innate immune cells [104-106]. To date, in human 11 TLRs family members have been identified in the human [107109]. Bacterial DNA is containing unmethylated CpG motifs which are able to act as important regulators of human neutrophil functions via TLR9. For example, stimulation of the TLR9 pathway via CpG oligonucleotides (ODN) induces CXCL8 production by neutrophils via the generation of peroxynitrite (ONOO-) [110, 111]. 


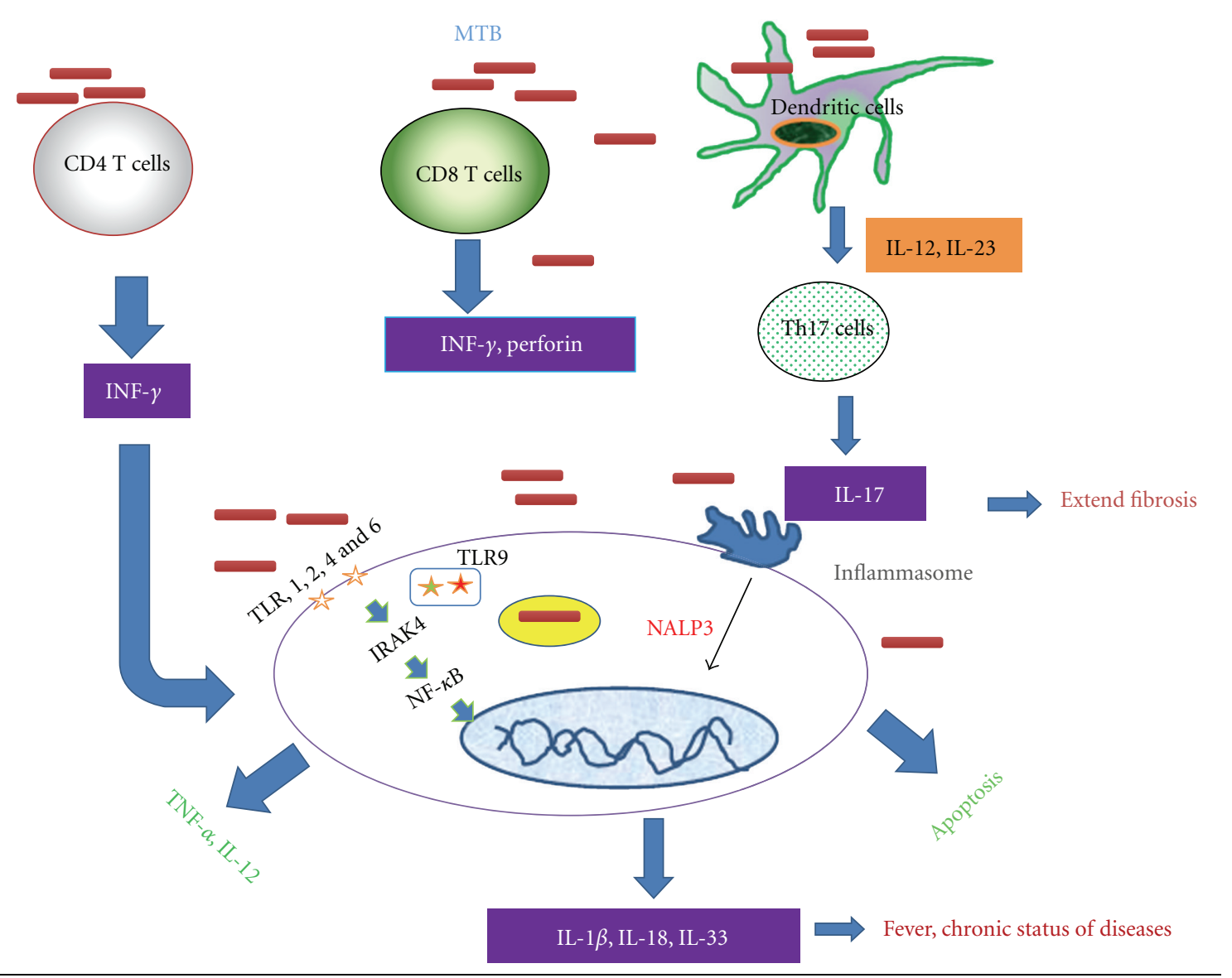

FIGURE 1: Schematic diagram of immunopathology of TB. After inhalation of MTB, the immune system cells (CD4, CD8, DCs, and Th17) were activated. By these T cells, Th1 cytokines were released. In next steps by involvements of released mediators especially IFN- $\gamma$, lungs macrophages were activated. After activation of macrophages by MTB or cytokines, inflammatory mediators such as IL- 12 and TNF- $\alpha$ or inflammasome mediators such as IL-1 $\beta$ via TLRs or inflammsome signal transduction pathways were released. Besides of activation, macrophages underwent to the apoptosis processing which is described as a main host protection strategy against the TB infection. Abbreviations used are: MTB; mycobacterium tuberculosis, TLR; toll-like receptors.

Upon inhalation, MTB travels to the lung where it infects resident alveolar macrophages [112]. This initial infection leads to an innate immune response, which includes stimulation of TLRs that recognize pathogens and are located on the plasma membrane and within endosomes of host cells. Emerging of data indicated that MTB is specifically recognized by TLRs 2,4 , and 9 [113].

TLR activation upregulates transcription of proinflammatory cytokines IL- $1 \beta$, TNF- $\alpha$, and IL- 6 , which are essential for the recruitment of immune cells to the site of infection and controlling MTB infection $[114,115]$.

Mice deficient in the TLR/IL-1R family receptor adaptor molecule MyD88 have been shown to be highly susceptible to infection with MTB, which could be suggested to major role for this pathway in innate defense against the MTB $[116,117]$. In this line it has been demonstrated that TB induces ROS in cells which accounts for the induction of proinflammatory cytokines [118].

Besides, it has been shown that TLR2-ROS signaling could play a crucial role in the expression of CXCL8 and
CCL2 in human monocytes. In addition, both p38 and ERK1/2 activations are essential for $30-\mathrm{kDa}$ Ag-stimulated CCL2 production by monocytes [119]. In correspondence, earlier studies by using human overexpressed TLR2 or TLR4 cell lines suggested that viable MTB could activate cells via both TLR2 and TLR4 pathways [120].

Recent studies in mice with inactivated TLR genes showed that TLR2 is important in controlling and surviving the MTB infection $[121,122]$. However, some observations suggested that TLR4 is also important for survival of MTB infection [123-125]. However, other studies indicated that the importance of TLR4 may depend on the dose of MTB used for challenge [126] or the choice of mouse strain [127].

In this regard, human studies show that polymorphisms of TLR2 or TLR4 may result in increased susceptibility to microbial infections, possibly by changing the balance of Th1/Th2 response [128-132]. Interestingly, Fenhalls et al. reported that the expression of TLR in TB lung granulomas is related to the presence or absence of immunohistologically detectable IL-4 [133]. Now it became clear that changes 
in TLR expression might represent useful markers of the immunological status of patients and their contacts. When examining the TLR distribution in TB granulomas lesions, it was shown that TLR1, TLR2, and TLR4 were expressed in both immune cells and nonimmune cells; however, TLR9 was detectable in immune cells [134]. In an animal model with TB, it has been shown that TLR8-deficient mice succumb rapidly to infection with $M$. tuberculosis, despite controlling efficiently the infection in different organs. Exaggerated mortality was due to massive liver necrosis and was reversed by in vivo treatment with Abs to IL- 1 and TNF- $\alpha$. Thus, TLR8 plays a key role in damping inflammation and tissue damage in M. tuberculosis infection [135].

3.2. Role of Inflammasomes Signaling in MTB. In addition to TLR recognition, a newly discovered class of intracellular danger-sensing proteins, the nucleotide-binding domain, leucine-rich repeats containing family proteins known as NLRs, sense pathogens and pathogen products in the cell cytoplasm [136]. With more than twenty members, the NLRs function in host protection against a broad range of danger signals. Several NLRs function in immunity through the formation of a multiprotein complex known as an inflammasome [137]. The importance of inflammasome signaling against MBT previously has been described. For example, it has shown that M. marinum, a mycobacterium that naturally infects fish and amphibians, activates IL- $1 \beta$ production in a NLRP3, and caspase-1-dependent manner in vitro, but no in vivo investigation was conducted [138]. Another report showed that $M$. bovis BCG, the vaccine strain of $\mathrm{Mtb}$, can limit caspase- 1 and IL- $1 \beta$ activation due to a putative protease Zmp1. In this latter study, however, there was no analysis of Pycard, Nlrp3 or Nlrc4, to directly implicate the inflammasome components [139]. Finally it has shown that MTB-infected THP-1 human monocyte cell line secretes IL$1 \beta$ in a PYCARD and NLRP3-dependent process, but did not investigate the role of the inflammasome in vivo [140]. When activated by a specific danger signal, the inflammasome forms and results in recruitment and processing of procaspase-1, which in turn processes IL- $1 \beta$ and IL-18 to their active forms for secretion from macrophages. Although the host's innate immune response to MTB infection is critical for the initial defense against bacteria, the adaptive immune response is ultimately required for containment of the infection in the chronic stage of disease. Adaptive immunity to MTB infection is characterized by the appearance of antigen-specific $\mathrm{CD}^{+}{ }^{+} \mathrm{T}$ cells that secrete interferon gamma $(\mathrm{IFN}-\gamma)$, which is responsible for activating macrophages to kill intracellular bacteria [141]. $\mathrm{CD}^{+} \mathrm{T}$ cells are also important for controlling bacteria during the chronic phase of MTB infection [142]. Chronic MTB infection is controlled by granuloma formation which contains, but does not eliminate bacteria [143]. IL- $1 \beta$ induces the release of GMCSF which leads to the activation and increased survival of monocytes/macrophages and enhanced oxidative burst in the lungs; thus, maintaining and prolonging inflammatory reactions, IL- $1 \beta$ is secreted by activation of inflammasome signaling which is triggered by signal transduction via TLRs and purinergic receptors. Apoptosis-associated speck-like protein, containing a caspase recruit domain (ASC) and procaspase 1, forms a multimeric cytosolic molecular complex known as the NALP3 proinflammatory cytokine regulation can be critical to long-term survival of $\mathrm{Mtb}$ infection. In vivo assessments of IL- $1 \alpha / \beta^{-/-}$, IL-1R ${ }^{-/-}$, and IL- $18^{-/-}$mice have shown that these cytokines play a role in limiting bacterial lung burden, regulating other cytokines, nitric oxide production, and forming organized granulomas [144146]. Recently it has been shown that caspase- 1 independent IL- $1 \beta$ production is critical for host resistance to MTB and does not require TLR signaling in vivo. Besides they show that ( although IL-1 $\beta$ induction by MTB in vitro depends on TLR triggering and the inflammasome for signals 1 and 2 respectively, both triggers are dispensable for IL-1 $\beta$ production in vivo in mice infected with the pathogen [147].

In this regard, recently it has been reported that here we show that MTB-induced IL- $1 \beta$ secretion in human and mouse macrophages in vitro, and this process was dependent on PYCARD, caspase-1, and NLRP3, but not NLCR4. In vivo, murine Pycard helps protect the host from death during chronic MTB infection while the effects of Casp-1 and NLP3 were negligible. The inability of Pycard ${ }^{-1-}$ mice to form organized granulomas and the reduced presence of lung dendritic cells indicate a breakdown in host defense against MTB. Thus, we identify PYCARD as a critical protein involved in host response to MTB infection in an inflammasome-independent manner [148].

\section{Conclusion and Future Research}

TB is a chronic disease with protection strongly depending on mycobacterial containment. The mechanisms underlying this containment are highly complex comprising different $\mathrm{T}$ cell populations with their complex signaling. Although CD4 T cells, CD8 T cells, $\gamma \delta \mathrm{T}$ cells, macrophages, and DCs are apparently important role in the pathogenesis of TB; however, the exact mechanisms of the TB and crosstalk between involved cells are not well described.

Although $\mathrm{T}$ cells are the major mediators of protection against the $\mathrm{TB}$, effector functions are mostly provided by macrophages/DCs which is not much appreciated. The crosstalk between $\mathrm{T}$ cells and macrophages and DCs is achieved by various cytokines, notably IFN- $\gamma$, TNF- $\alpha$, IL-17, and IL-1- $\beta$. This cross talk first results in APC activation, that is, the ability of APC to control MTB replication (Figure 1). Taken together, present literature suggests a role for novel signal transductions and molecules in pathogenesis of TB. Currently available animal models for TB could be employed to further address the role of new cells such as Th17, Treg, and their possible value as therapeutic target in the treatment of TB.

\section{Abbreviations}

AMP: Adenosine monophosphate

APC: Antigen-presenting cell

BAL: Bronchoalveolar 


$\begin{array}{ll}\text { CCR: } & \text { CC-chemokine receptor } \\ \text { CDC: } & \text { Conventional dendritic cell } \\ \text { CD8 }{ }^{-} \text {cDC: } & \text { CD8 }{ }^{-} \text {conventional dendritic cell } \\ \text { CD8 }{ }^{+} \text {cDC: } & \text { CD8 }{ }^{+} \text {conventional dendritic cell } \\ \text { COPD: } & \text { Chronic obstructive pulmonary disease } \\ \text { CXCL: } & \text { CXC-chemokine ligand } \\ \text { CTL: } & \text { Cytotoxic T lymphocytes } \\ \text { CMR: } & \text { Cell-mediated reactions } \\ \text { CLR: } & \text { C-type lectin receptors } \\ \text { DTH: } & \text { Delayed-type hypersensitivity } \\ \text { DCs: } & \text { Dendritic cells } \\ \text { IFN- } \gamma: & \text { Interferon gamma } \\ \text { LPS: } & \text { Lipopolysaccharide } \\ \text { LT } \alpha: & \text { Lymphotoxin } \alpha \\ \text { MTB: } & \text { Mycobacterium tuberculosis } \\ \text { MMPs: } & \text { Matrix metalloproteinase } \\ \text { NK: } & \text { Natural killer cells } \\ \text { NOS2: } & \text { Nitric oxide synthase 2 } \\ \text { ODN: } & \text { Oligodeoxyribonucleotides } \\ \text { ONOO: } & \text { Peroxynitrite } \\ \text { PRRs: } & \text { Pattern recognition receptors } \\ \text { PAMPs: } & \text { Pathogen-associated molecular patterns } \\ \text { pDC: } & \text { Plasmacytoid dendritic cell } \\ \text { PMN: } & \text { Polymorphonuclear cells } \\ \text { ROS: } & \text { Reactive oxygen species } \\ \text { TLR: } & \text { Toll-like receptor } \\ \text { TB: } & \text { Tuberculosis. }\end{array}$

\section{References}

[1] N. W. Schluger, "Recent advances in our understanding of human host responses to tuberculosis," Respiratory Research, vol. 2, no. 3, pp. 157-163, 2001.

[2] World Health Organization, "Global tuberculosis control 2010," WHO Report 201, World Health Organization, Geneva, Switzerlands.

[3] World Health Organization, "Global tuberculosis control," WHO Report WHO/CDS/TB/2001.287, World Health Organization, Geneva, Switzerlands, 2001.

[4] S. Malik and E. Schurr, "Genetic susceptibility to tuberculosis," Clinical Chemistry and Laboratory Medicine, vol. 40, no. 9, pp. 863-868, 2002.

[5] J. Kleinnijenhuis, M. Oosting, L. A.B. Joosten, M. G. Netea, and R. Van Crevel, "Innate immune recognition of Mycobacterium tuberculosis," Clinical and Developmental Immunology, vol. 2011, Article ID 405310, 12 pages, 2011.

[6] H. Saiga, Y. Shimada, and K. Takeda, "Innate immune effectors in mycobacterial infection," Clinical and Developmental Immunology, vol. 2011, Article ID 347594, 8 pages, 2011.

[7] A. Mortellaro, L. Robinson, and R. C. Paola, "Spotlight on mycobacteria and dendritic cells: will novel targets to fight tuberculosis emerge?" EMBO Molecular Medicine, vol. 1, no. 1, pp. 19-29, 2009.

[8] N. W. Schluger and W. N. Rom, "The host immune response to tuberculosis," American Journal of Respiratory and Critical Care Medicine, vol. 157, no. 3, pp. 679-691, 1998.

[9] R. L. Coffman and S. Romagnani, Redirection of Th1 and Th2 Responses, Springer, Berlin, Germany, 1999.

[10] T. R. Mosmann and S. Sad, "The expanding universe of T-cell subsets: Th1, Th2 and more," Immunology Today, vol. 17, no. 3, pp. 138-146, 1996.
[11] S. Romagnani and T. Mosmann, "Human $\mathrm{T}(\mathrm{H}) 1$ and $\mathrm{T}(\mathrm{H}) 2$ subsets: doubt no more," Immunology Today, vol. 12, no. 8, pp. 256-257, 1991.

[12] P. A. Sieling and R. L. Modlin, "Cytokine patterns at the site of mycobacterial infection," Immunobiology, vol. 191, no. 4-5, pp. 378-387, 1994.

[13] Y. Suzuki, F. K. Conley, and J. S. Remington, "Importance of endogenous IFN- $\gamma$ for prevention of toxoplasmic encephalitis in mice," Journal of Immunology, vol. 143, no. 6, pp. 20452050, 1989.

[14] H. Kornfeld, G. Mancino, and V. Colizzi, "The role of macrophage cell death in tuberculosis," Cell Death and Differentiation, vol. 6, no. 1, pp. 71-78, 1999.

[15] M. Niederweis, O. Danilchanka, J. Huff, C. Hoffmann, and H. Engelhardt, "Mycobacterial outer membranes: in search of proteins," Trends in Microbiology, vol. 18, no. 3, pp. 109116, 2010.

[16] S. Ahmad, "Pathogenesis, immunology, and diagnosis of latent Mycobacterium tuberculosis infection," Clinical and Developmental Immunology, vol. 2011, Article ID 814943, 17 pages, 2011.

[17] S. Brighenti and J. Andersson, "Induction and regulation of CD8+ cytolytic T cells in human tuberculosis and HIV infection," Biochemical and Biophysical Research Communications, vol. 396, no. 1, pp. 50-57, 2010.

[18] S. Stenger, "Cytolytic T cells in the immune response to Mycobacterium tuberculosis," Scandinavian Journal of Infectious Diseases, vol. 33, no. 7, pp. 483-487, 2001.

[19] L. F. Barker, M. J. Brennan, P. K. Rosenstein, and J. C. Sadoff, "Tuberculosis vaccine research: the impact of immunology," Current Opinion in Immunology, vol. 21, no. 3, pp. 331-338, 2009.

[20] R. J. North and Y. J. Jung, "Immunity to tuberculosis," Annual Review of Immunology, vol. 22, pp. 599-623, 2004.

[21] S. H. E. Kaufmann, "Protection against tuberculosis: cytokines, T cells, and macrophages," Annals of the Rheumatic Diseases, vol. 61, supplement 2, pp. 54-58, 2002.

[22] S. N. M. Hanif, R. Al-Attiyah, and A. S. Mustafa, "Speciesspecific antigenic Mycobacterium tuberculosis proteins tested by delayed-type hypersensitivity response," International Journal of Tuberculosis and Lung Disease, vol. 14, no. 4, pp. 489-494, 2010.

[23] J. L. Flynn, J. Chan, and P. L. Lin, "Macrophages and control of granulomatous inflammation in tuberculosis," Mucosal Immunology, vol. 4, no. 3, pp. 271-278, 2011.

[24] H. P. Gideon and J. L. Flynn, "Latent tuberculosis: what the host "sees"?" Immunologic Research, vol. 50, no. 2-3, pp. 202212, 2011.

[25] S. H. E. Kaufmann, "The macrophage in tuberculosis: sinner of saint? The T cell decides," Pathobiology, vol. 59, no. 3, pp. 153-155, 1991.

[26] J. A. Philips and J. D. Ernst, "Tuberculosis pathogenesis and immunity," Annual Review of Pathology, vol. 7, pp. 353-384, 2012.

[27] D. Sud, C. Bigbee, J. L. Flynn, and D. E. Kirschner, "Contribution of CD8 ${ }^{+} \mathrm{T}$ cells to control of Mycobacterium tuberculosis infection," Journal of Immunology, vol. 176, no. 7, pp. 4296-4314, 2006.

[28] J. Turner and H. M. Dockrell, "Stimulation of human peripheral blood mononuclear cells with live mycobacterium bovis BCG activates cytolytic CD8+ T cells in vitro," Immunology, vol. 87, no. 3, pp. 339-342, 1996.

[29] D. H. Canaday, R. J. Wilkinson, Q. Li, C. V. Harding, R. F. Silver, and W. H. Boom, "CD4 ${ }^{+}$and $\mathrm{CD}^{+} \mathrm{T}$ cells 
kill intracellular Mycobacterium tuberculosis by a perforin and Fas/Fas ligand-independent mechanism," Journal of Immunology, vol. 167, no. 5, pp. 2734-2742, 2001.

[30] T. Mutis, Y. E. Cornelisse, and T. H. M. Ottenhoff, "Mycobacteria induce $\mathrm{CD}^{+}{ }^{+} \mathrm{T}$ cells that are cytotoxic and display Th1like cytokine secretion profile: heterogeneity in cytotoxic activity and cytokine secretion levels," European Journal of Immunology, vol. 23, no. 9, pp. 2189-2195, 1993.

[31] F. Dieli, M. Troye-Blomberg, J. Ivanyi et al., "V $\gamma 9 / \mathrm{V} \delta 2 \mathrm{~T}$ lymphocytes reduce the viability of intracellular Mycobacterium tuberculosis," European Journal of Immunology, vol. 30, no. 5, pp. 1512-1519, 2000.

[32] C. H. Ladel, C. Blum, A. Dreher, K. Reifenberg, and S. H. E. Kaufmann, "Protective role of $\gamma / \delta$ T cells and $\alpha / \beta$ T cells in tuberculosis," European Journal of Immunology, vol. 25, no. 10, pp. 2877-2881, 1995.

[33] F. J. Culley, "Natural killer cells in infection and inflammation of the lung," Immunology, vol. 128, no. 2, pp. 151-163, 2009.

[34] A. Raja, "Immunology of tuberculosis," Indian Journal of Medical Research, vol. 120, no. 4, pp. 213-232, 2004.

[35] X. Chen, B. Zhou, M. Li et al., "CD4 $4_{+} \mathrm{CD} 25_{+} \mathrm{FoxP}_{+}$regulatory T cells suppress Mycobacterium tuberculosis immunity in patients with active disease," Clinical Immunology, vol. 123, no. 1, pp. 50-59, 2007.

[36] V. Guyot-Revol, J. A. Innes, S. Hackforth, T. Hinks, and A. Lalvani, "Regulatory $\mathrm{T}$ cells are expanded in blood and disease sites in patients with tuberculosis," American Journal of Respiratory and Critical Care Medicine, vol. 173, no. 7, pp. 803-810, 2006.

[37] R. Ribeiro-Rodrigues, T. Resende Co, R. Rojas et al., “A role for $\mathrm{CD} 4_{+} \mathrm{CD} 25_{+} \mathrm{T}$ cells in regulation of the immune response during human tuberculosis," Clinical and Experimental Immunology, vol. 144, no. 1, pp. 25-34, 2006.

[38] S. A. Khader, J. E. Pearl, K. Sakamoto et al., "IL-23 compensates for the absence of IL-12p70 and is essential for the IL-17 response during tuberculosis but is dispensable for protection and antigen-specific IFN- $\gamma$ responses if IL-12p70 is available," Journal of Immunology, vol. 175, no. 2, pp. 788795, 2005.

[39] S. Sergejeva, S. Ivanov, J. Lötvall, and A. Lindén, “Interleukin17 as a recruitment and survival factor for airway macrophages in allergic airway inflammation," American Journal of Respiratory Cell and Molecular Biology, vol. 33, no. 3, pp. 248-253, 2005.

[40] J. K. Kolls and A. Lindén, "Interleukin-17 family members and inflammation," Immunity, vol. 21, no. 4, pp. 467-476, 2004.

[41] M. Miyamoto, O. Prause, M. Sjöstrand, M. Laan, J. Lötvall, and A. Lindén, "Endogenous IL-17 as a mediator of neutrophil recruitment caused by endotoxin exposure in mouse airways," Journal of Immunology, vol. 170, no. 9, pp. 4665 4672, 2003.

[42] M. A. Stark, Y. Huo, T. L. Burcin, M. A. Morris, T. S. Olson, and K. Ley, "Phagocytosis of apoptotic neutrophils regulates granulopoiesis via IL-23 and IL-17," Immunity, vol. 22, no. 3, pp. 285-294, 2005.

[43] S. Sergejeva, S. Ivanov, J. Lötvall, and A. Lindén, "Interleukin17 as a recruitment and survival factor for airway macrophages in allergic airway inflammation," American Journal of Respiratory Cell and Molecular Biology, vol. 33, no. 3, pp. 248-253, 2005.

[44] S. A. Khader, G. K. Bell, J. E. Pearl et al., "IL-23 and IL17 in the establishment of protective pulmonary $\mathrm{CD} 4_{+} \mathrm{T}$ cell responses after vaccination and during Mycobacterium tuberculosis challenge," Nature Immunology, vol. 8, no. 4, pp. 369-377, 2007.

[45] F. Shen, Z. Hu, J. Goswami, and S. L. Gaffen, "Identification of common transcriptional regulatory elements in interleukin-17 target genes," Journal of Biological Chemistry, vol. 281, no. 34, pp. 24138-24148, 2006.

[46] J. Lee, M. Hartman, and H. Kornfeld, "Macrophage apoptosis in tuberculosis," Yonsei Medical Journal, vol. 50, no. 1, pp. 1$11,2009$.

[47] L. S. Schlesinger, "Macrophage phagocytosis of virulent but not attenuated strains of Mycobacterium tuberculosis is mediated by mannose receptors in addition to complement receptors," Journal of Immunology, vol. 150, no. 7, pp. 29202930, 1993.

[48] S. Zimmerli, S. Edwards, and J. D. Ernst, "Selective receptor blockade during phagocytosis does not alter the survival and growth of Mycobacterium tuberculosis in human macrophages," American Journal of Respiratory Cell and Molecular Biology, vol. 15, no. 6, pp. 760-770, 1996.

[49] P. Schierloh, N. Yokobori, M. Alemán et al., "Mycobacterium tuberculosis-induced gamma interferon production by natural killer cells requires cross talk with antigen-presenting cells involving toll-like receptors 2 and 4 and the mannose receptor in tuberculous pleurisy," Infection and Immunity, vol. 75, no. 11, pp. 5325-5337, 2007.

[50] A. J. Gehring, R. E. Rojas, D. H. Canaday, D. L. Lakey, C. V. Harding, and W. H. Boom, "The Mycobacterium tuberculosis 19-kilodalton lipoprotein inhibits gamma interferonregulated HLA-DR and Fc $\gamma \mathrm{R} 1$ on human macrophages through toll-like receptor 2," Infection and Immunity, vol. 71, no. 8, pp. 4487-4497, 2003.

[51] F. C. Lin, Y. C. Chen, F. J. Chen, and S. C. Chang, "Cytokines and fibrinolytic enzymes in tuberculous and parapneumonic effusions," Clinical Immunology, vol. 116, no. 2, pp. 166-173, 2005.

[52] K. Rohde, R. M. Yates, G. E. Purdy, and D. G. Russell, "Mycobacterium tuberculosis and the environment within the phagosome," Immunological Reviews, vol. 219, no. 1, pp. 3754, 2007.

[53] D. L. Clemens and M. A. Horwitz, "Characterization of the Mycobacterium tuberculosis phagosome and evidence that phagosomal maturation is inhibited," Journal of Experimental Medicine, vol. 181, no. 1, pp. 257-270, 1995.

[54] I. P. Fairbairn, "Macrophage apoptosis in host immunity to mycobacterial infections," Biochemical Society Transactions, vol. 32, no. 3, pp. 496-498, 2004.

[55] C. de Chastellier, "The many niches and strategies used by pathogenic mycobacteria for survival within host macrophages," Immunobiology, vol. 214, no. 7, pp. 526-542, 2009.

[56] N. Ismail, J. P. Olano, H. M. Feng, and D. H. Walker, "Current status of immune mechanisms of killing of intracellular microorganims," FEMS Microbiology Letters, vol. 207, no. 2, pp. 111-120, 2002.

[57] M. G. Gutierrez, S. S. Master, S. B. Singh, G. A. Taylor, M. I. Colombo, and V. Deretic, "Autophagy is a defense mechanism inhibiting BCG and Mycobacterium tuberculosis survival in infected macrophages," Cell, vol. 119, no. 6, pp. 753-766, 2004.

[58] G. E. Purdy and D. G. Russell, "Lysosomal ubiquitin and the demise of Mycobacterium tuberculosis," Cellular Microbiology, vol. 9, no. 12, pp. 2768-2774, 2007.

[59] J. Lee, H. G. Remold, M. H. Ieong, and H. Kornfeld, "Macrophage apoptosis in response to high intracellular 
burden of Mycobacterium tuberculosis is mediated by a novel caspase-independent pathway," Journal of Immunology, vol. 176, no. 7, pp. 4267-4274, 2006.

[60] J. S. Park, M. H. Tamayo, M. Gonzalez-Juarrero, I. M. Orme, and D. J. Ordway, "Virulent clinical isolates of Mycobacterium tuberculosis grow rapidly and induce cellular necrosis but minimal apoptosis in murine macrophages," Journal of Leukocyte Biology, vol. 79, no. 1, pp. 80-86, 2006.

[61] J. Hinchey, S. Lee, B. Y. Jeon et al., "Enhanced priming of adaptive immunity by a proapoptotic mutant of Mycobacterium tuberculosis," Journal of Clinical Investigation, vol. 117, no. 8, pp. 2279-2288, 2007.

[62] D. M. Lowe, P. S. Redford, R. J. Wilkinson, A. O'Garra, and A. R. Martineau, "Neutrophils in tuberculosis: friend or foe?" Trends in Immunology, vol. 33, no. 1, pp. 14-25, 2012.

[63] K. F. Law, J. Jagirdar, M. D. Weiden, M. Bodkin, and W. N. Rom, "Tuberculosis in HIV-positive patients: cellular response and immune activation in the lung," American Journal of Respiratory and Critical Care Medicine, vol. 153, no. 4, pp. 1377-1384, 1996.

[64] V. B. Antony, S. A. Sahn, R. N. Harada, and J. E. Repine, "Lung repair and granuloma formation. Tubercle bacilli stimulated neutrophils release chemotactic factors for monocytes," Chest, vol. 83, no. 5, 1983.

[65] R. Appelberg and M. T. Silva, "T cell-dependent chronic neutrophilia during mycobacterial infections," Clinical and Experimental Immunology, vol. 78, no. 3, pp. 478-483, 1989.

[66] J. Pedrosa, B. M. Saunders, R. Appelberg, I. M. Orme, M. T. Silva, and A. M. Cooper, "Neutrophils play a protective nonphagocytic role in systemic Mycobacterium tuberculosis infection of mice," Infection and Immunity, vol. 68, no. 2, pp. 577-583, 2000.

[67] P. Hartmann, R. Becker, C. Franzen et al., "Phagocytosis and killing of Mycobacterium avium complex by human neutrophils," Journal of Leukocyte Biology, vol. 69, no. 3, pp. 397-404, 2001.

[68] J. Banchereau and R. M. Steinman, "Dendritic cells and the control of immunity," Nature, vol. 392, no. 6673, pp. 245 252, 1998.

[69] R. M. Steinman, "Dendritic cells," in Fundamental Immunology, W. E. Paul, Ed., p. 547, Lippincott-Raven, New York, NY, USA, 1999.

[70] R. E. Tascon, C. S. Soares, S. Ragno, E. Stavropoulos, E. M. A. Hirst, and M. J. Colston, "Mycobacterium tuberculosisactivated dendritic cells induce protective immunity in mice," Immunology, vol. 99, no. 3, pp. 473-480, 2000.

[71] T. Tian, J. Woodworth, M. Sköld, and S. M. Behar, "In vivo depletion of $\mathrm{CD} 11 \mathrm{c}_{+}$cells delays the $\mathrm{CD} 4_{+} \mathrm{T}$ cell response to Mycobacterium tuberculosis and exacerbates the outcome of infection," Journal of Immunology, vol. 175, no. 5, pp. 32683272, 2005.

[72] A. A. Chackerian, J. M. Alt, T. V. Perera, C. C. Dascher, and S. M. Behar, "Dissemination of Mycobacterium tuberculosis is influenced by host factors and precedes the initiation of T-cell immunity," Infection and Immunity, vol. 70, no. 8, pp. 4501-4509, 2002.

[73] I. R. Humphreys, G. R. Stewart, D. J. Turner et al., "A role for dendritic cells in the dissemination of mycobacterial infection," Microbes and Infection, vol. 8, no. 5, pp. 13391346, 2006.

[74] S. A. Khader, J. E. Pearl, K. Sakamoto et al., "IL-23 compensates for the absence of IL-12p70 and is essential for the IL-17 response during tuberculosis but is dispensable for protection and antigen-specific IFN- $\gamma$ responses if IL-12p70 is available," Journal of Immunology, vol. 175, no. 2, pp. 788795, 2005.

[75] E. Lockhart, A. M. Green, and J. L. Flynn, "IL-17 production is dominated by $\gamma \delta \mathrm{T}$ cells rather than CD4 T cells during Mycobacterium tuberculosis infection," Journal of Immunology, vol. 177, no. 7, pp. 4662-4669, 2006.

[76] T. M. Wozniak, A. A. Ryan, J. A. Triccas, and W. J. Britton, "Plasmid interleukin-23 (IL-23), but not plasmid IL-27, enhances the protective efficacy of a DNA vaccine against Mycobacterium tuberculosis infection," Infection and Immunity, vol. 74, no. 1, pp. 557-565, 2006.

[77] R. C.M. Ryan, M. P. O’Sullivan, and J. Keane, “Mycobacterium tuberculosis infection induces non-apoptotic cell death of human dendritic cells," BMC Microbiology, vol. 11, no. 1, p. 237, 2011.

[78] G. Pier, J. Lyczak, and L. Wetzler, "Cell mediated immunity," in Immunology, Infection, and Immunity, ASM Press, Washington, DC, USA, 2004.

[79] J. Harris, S. A. De Haro, S. S. Master et al., "T helper 2 cytokines inhibit autophagic control of intracellular Mycobacterium tuberculosis," Immunity, vol. 27, no. 3, pp. 505-517, 2007.

[80] I. Vergne, S. Singh, E. Roberts et al., "Autophagy in immune defense against Mycobacterium tuberculosis," Autophagy, vol. 2, no. 3, pp. 175-178, 2006.

[81] G. Tully, C. Kortsik, H. Höhn et al., "Highly focused T cell responses in latent human pulmonary Mycobacterium tuberculosis infection," Journal of Immunology, vol. 174, no. 4, pp. 2174-2184, 2005.

[82] L. Szereday, Z. Baliko, and J. Szekeres-Bartho, “ $\gamma / \delta$ T cell subsets in patients with active Mycobacterium tuberculosis infection and tuberculin anergy," Clinical and Experimental Immunology, vol. 131, no. 2, pp. 287-291, 2003.

[83] L. E. Bermudez and J. Goodman, "Mycobacterium tuberculosis invades and replicates within type II alveolar cells," Infection and Immunity, vol. 64, no. 4, pp. 1400-1406, 1996.

[84] R. Teitelbaum, W. Schubert, L. Gunther et al., "The M cell as a portal of entry to the lung for the bacterial pathogen Mycobacterium tuberculosis," Immunity, vol. 10, no. 6, pp. 641-650, 1999.

[85] S. M. Mirsaeidi, M. R. Masjedi, S. D. Mansouri, and A. A. Velayati, "Tuberculosis of the breast: report of 4 clinical cases and literature review," Eastern Mediterranean Health Journal, vol. 13, no. 3, pp. 670-676, 2007.

[86] G. J. Wise, "Urinary tuberculosis: modern issues," Current Urology Reports, vol. 10, no. 4, pp. 313-318, 2009.

[87] J. Keane, S. Gershon, R. P. Wise et al., "Tuberculosis associated with infliximab, a tumor necrosis factor $\alpha$-neutralizing agent," New England Journal of Medicine, vol. 345, no. 15, pp. 1098-1104, 2001.

[88] D. A. Lammas, J. L. Casanova, and D. S. Kumararatne, "Clinical consequences of defects in the IL-12-dependent interferon-gamma (IFN- $\gamma$ ) pathway," Clinical and Experimental Immunology, vol. 121, no. 3, pp. 417-425, 2000.

[89] F. L. Van De Veerdonk, A. C. Teirlinck, J. Kleinnijenhuis et al., "Mycobacterium tuberculosis induces IL-17A responses through TLR4 and dectin-1 and is critically dependent on endogenous IL-1," Journal of Leukocyte Biology, vol. 88, no. 2, pp. 227-232, 2010.

[90] D. Gupta, S. Sharma, J. Singhal, A. T. Satsangi, C. Antony, and K. Natarajan, "Suppression of TLR2-induced il-12, reactive oxygen species, and inducible nitric oxide synthase expression by Mycobacterium tuberculosis antigens expressed 
inside macrophages during the course of infection," Journal of Immunology, vol. 184, no. 10, pp. 5444-5455, 2010.

[91] G. A. W. Rook, "Th2 cytokines in susceptibility to tuberculosis," Current Molecular Medicine, vol. 7, no. 3, pp. 327-337, 2007.

[92] R. Hernández-Pando, H. Orozcoe, A. Sampieri et al., "Correlation between the kinetics of Th1/Th2 cells and pathology in a murine model of experimental pulmonary tuberculosis," Immunology, vol. 89, no. 1, pp. 26-33, 1996.

[93] A. Aderem and R. J. Ulevitch, "Toll-like receptors in the induction of the innate immune response," Nature, vol. 406, no. 6797 , pp. 782-787, 2000.

[94] R. Medzhitov, P. Preston-Hurlburt, and C. A. Janeway, "A human homologue of the Drosophila toll protein signals activation of adaptive immunity," Nature, vol. 388 , no. 6640, pp. 394-397, 1997.

[95] S. L. Doyle and L. A. J. O’Neill, “Toll-like receptors: from the discovery of $\mathrm{NF} \kappa \mathrm{B}$ to new insights into transcriptional regulations in innate immunity," Biochemical Pharmacology, vol. 72, no. 9, pp. 1102-1113, 2006.

[96] L. Gan and L. Li, "Regulations and roles of the interleukin-1 receptor associated kinases (IRAKs) in innate and adaptive immunity," Immunologic Research, vol. 35, no. 3, pp. 295302, 2006.

[97] K. Takeda, T. Kaisho, and S. Akira, "Toll-like receptors," Annual Review of Immunology, vol. 21, pp. 335-376, 2003.

[98] A. Aderem and R. J. Ulevitch, "Toll-like receptors in the induction of the innate immune response," Nature, vol. 406, no. 6797, pp. $782-787,2000$.

[99] S. Akira and H. Hemmi, "Recognition of pathogenassociated molecular patterns by TLR family," Immunology Letters, vol. 85, no. 2, pp. 85-95, 2003.

[100] E. A. Kurt-Jones, L. Popova, L. Kwinn et al., "Pattern recognition receptors TLR4 and CD14 mediate response to respiratory syncytial virus," Nature Immunology, vol. 1, no. 5, pp. 398-401, 2000.

[101] A. Aderem and R. J. Ulevitch, "Toll-like receptors in the induction of the innate immune response," Nature, vol. 406, no. 6797, pp. 782-787, 2000.

[102] S. Akira and H. Hemmi, "Recognition of pathogenassociated molecular patterns by TLR family," Immunology Letters, vol. 85, no. 2, pp. 85-95, 2003.

[103] E. A. Kurt-Jones, L. Popova, L. Kwinn et al., "Pattern recognition receptors TLR4 and CD14 mediate response to respiratory syncytial virus," Nature Immunology, vol. 1, no. 5, pp. 398-401, 2000.

[104] S. Khare, N. Luc, A. Dorfleutner, and C. Stehlik, "Inflammasomes and their activation," Critical Reviews in Immunology, vol. 30, no. 5, pp. 463-487, 2010.

[105] T. Kawai and S. Akira, "The role of pattern-recognition receptors in innate immunity: update on toll-like receptors," Nature Immunology, vol. 11, no. 5, pp. 373-384, 2010.

[106] H. Kumar, T. Kawai, and S. Akira, "Toll-like receptors and innate immunity," Biochemical and Biophysical Research Communications, vol. 388, no. 4, pp. 621-625, 2009.

[107] M. Yamamoto and K. Takeda, "Current views of toll-like receptor signaling pathways," Gastroenterology Research and Practice, vol. 2010, Article ID 240365, 8 pages, 2010.

[108] T. Kawai and S. Akira, "Toll-like receptors and their crosstalk with other innate receptors in infection and immunity," Immunity, vol. 34, no. 5, pp. 637-650, 2011.

[109] H. Kumar, T. Kawai, and S. Akira, "Pathogen recognition by the innate immune system," International Reviews of Immunology, vol. 30, no. 1, pp. 16-34, 2011.
[110] E. Mortaz, I. M. Adcock, K. Ito, A. D. Kraneveld, F. P. Nijkamp, and G. Folkerts, "Cigarette smoke induces CXCL8 production by human neutrophils via activation of TLR9 receptor," European Respiratory Journal, vol. 36, no. 5, pp. 1143-1154, 2010.

[111] J. C. Leemans, N. P. Juffermans, S. Florquin et al., "Depletion of alveolar macrophages exerts protective effects in pulmonary tuberculosis in mice," Journal of Immunology, vol. 166, no. 7, pp. 4604-4611, 2001.

[112] V. Quesniaux, C. Fremond, M. Jacobs et al., "Toll-like receptor pathways in the immune responses to mycobacteria," Microbes and Infection, vol. 6, no. 10, pp. 946-959, 2004.

[113] C. H. Ladel, C. Blum, A. Dreher, K. Reifenberg, M. Kopf, and S. H. E. Kaufmann, "Lethal tuberculosis in interleukin-6deficient mutant mice," Infection and Immunity, vol. 65, no. 11, pp. 4843-4849, 1997.

[114] A. G. D. Bean, D. R. Roach, H. Briscoe et al., "Structural deficiencies in granuloma formation in TNF gene-targeted mice underlie the heightened susceptibility to aerosol Mycobacterium tuberculosis infection, which is not compensated for by lymphotoxin," Journal of Immunology, vol. 162, no. 6, pp. 3504-3511, 1999.

[115] H. Yamada, S. Mizumo, R. Horai, Y. Iwakura, and I. Sugawara, "Protective role of interleukin-1 in mycobacterial infection in IL-1 $\alpha / \beta$ double-knockout mice," Laboratory Investigation, vol. 80, no. 5, pp. 759-767, 2000.

[116] C. M. Fremond, V. Yeremeev, D. M. Nicolle, M. Jacobs, V. F. Quesniaux, and B. Ryffel, "Fatal Mycobacterium tuberculosis infection despite adaptive immune response in the absence of MyD88," Journal of Clinical Investigation, vol. 114, no. 12, pp. 1790-1799, 2004.

[117] C. A. Scanga, A. Bafica, C. G. Feng, A. W. Cheever, S. Hieny, and A. Sher, "MyD88-deficient mice display a profound loss in resistance to Mycobacterium tuberculosis associated with partially impaired th1 cytokine and nitric oxide synthase 2 expression," Infection and Immunity, vol. 72, no. 4, pp. 24002404, 2004

[118] D. M. Shin, B. Y. Jeon, H. M. Lee et al., "Mycobacterium tuberculosis eis regulates autophagy, inflammation, and cell death through redox-dependent signaling," PLoS Pathogens, vol. 6, no. 12, article e1001230, 2010.

[119] H. M. Lee, D. M. Shin, K. K. Kim, J. S. Lee, T. H. Paik, and E. K. Jo, "Roles of reactive oxygen species in CXCL8 and CCL2 expression in response to the $30-\mathrm{kDa}$ antigen of Mycobacterium tuberculosis," Journal of Clinical Immunology, vol. 29, no. 1, pp. 46-56, 2009.

[120] T. K. Means, S. Wang, E. Lien, A. Yoshimura, D. T. Golenbock, and M. J. Fenton, "Human Toll-like receptors mediate cellular activation by Mycobacterium tuberculosis," Journal of Immunology, vol. 163, no. 7, pp. 3920-3927, 1999.

[121] I. Sugawara, H. Yamada, C. Li, S. Mizuno, O. Takeuchi, and S. Akira, "Mycobacterial infection in TLR2 and TLR6 knockout mice," Microbiology and Immunology, vol. 47, no. 5, pp. 327336, 2003.

[122] M. B. Drennan, D. Nicolle, V. J.F. Quesniaux et al., “TollLike Receptor 2-Deficient Mice Succumb to Mycobacterium tuberculosis Infection," American Journal of Pathology, vol. 164, no. 1, pp. 49-57, 2004.

[123] B. Abel, N. Thieblemont, V. J. F. Quesniaux et al., "Tolllike receptor 4 expression is required to control chronic Mycobacterium tuberculosis infection in mice," Journal of Immunology, vol. 169, no. 6, pp. 3155-3162, 2002. 
[124] J. Branger, S. Knapp, S. Weijer et al., "Role of toll-like receptor 4 in gram-positive and gram-negative pneumonia in mice," Infection and Immunity, vol. 72, no. 2, pp. 788-794, 2004.

[125] A. A. Chackerian, T. V. Perera, and S. M. Behar, "Gamma interferon-producing $\mathrm{CD}^{+} \mathrm{T}$ lymphocytes in the lung correlate with resistance to infection with Mycobacterium tuberculosis," Infection and Immunity, vol. 69, no. 4, pp. 26662674, 2001.

[126] N. Reiling, C. Hölscher, A. Fehrenbach et al., "Cutting edge: toll-like receptor (TLR)2- and TLR4-mediated pathogen recognition in resistance to airborne infection with Mycobacterium tuberculosis," Journal of Immunology, vol. 169, no. 7, pp. 3480-3484, 2002.

[127] A. B. Kamath, J. Alt, H. Debbabi, and S. M. Behar, "Toll-like receptor 4-defective $\mathrm{C} 3 \mathrm{H} / \mathrm{Hej}$ mice are not more susceptible than other $\mathrm{C} 3 \mathrm{H}$ substrains to infection with Mycobacterium tuberculosis," Infection and Immunity, vol. 71, no. 7, pp. 41124118, 2003.

[128] S. R. Krutzik, M. T. Ochoa, P. A. Sieling et al., "Activation and regulation of Toll-like receptors 2 and 1 in human leprosy," Nature Medicine, vol. 9, no. 5, pp. 525-532, 2003.

[129] L. Alexopoulou, V. Thomas, M. Schnare et al., "Hyporesponsiveness to vaccination with Borrelia burgdorferi OspA in humans and in TLR1- and TLR2-deficient mice," Nature Medicine, vol. 8, no. 8, pp. 878-884, 2002.

[130] N. C. Arbour, E. Lorenz, B. C. Schutte et al., "TLR4 mutations are associated with endotoxin hyporesponsiveness in humans," Nature Genetics, vol. 25, no. 2, pp. 187-191, 2000.

[131] T. J. Kang, S. B. Lee, and G. T. Chae, "A polymorphism in the toll-like receptor 2 is associated with IL-12 production from monocyte in lepromatous leprosy," Cytokine, vol. 20, no. 2, pp. 56-62, 2002.

[132] E. Lorenz, J. P. Mira, K. L. Cornish, N. C. Arbour, and D. A. Schwartz, "A novel polymorphism in the toll-like receptor 2 gene and its potential association with staphylococcal infection," Infection and Immunity, vol. 68, no. 11, pp. 63986401, 2000.

[133] G. Fenhalls, G. R. Squires, L. Stevens-Muller et al., "Associations between toll-like receptors and interleukin-4 in the lungs of patients with tuberculosis," American Journal of Respiratory Cell and Molecular Biology, vol. 29, no. 1, pp. 28$38,2003$.

[134] G. A. Rook, K. Dheda, and A. Zumla, "Opinion: immune responses to tuberculosis in developing countries: implications for new vaccines," Nature Reviews Immunology, vol. 5, pp. 661-667, 2005.

[135] C. Garlanda, D. Di Liberto, A. Vecchi et al., "Damping excessive inflammation and tissue damage in Mycobacterium tuberculosis infection by toll IL-1 receptor 8/single Ig IL-1related receptor, a negative regulator of IL-1/TLR signaling," Journal of Immunology, vol. 179, no. 5, pp. 3119-3125, 2007.

[136] J. P. Y. Ting, R. C. Lovering, E. S. Alnemri et al., "The NLR Gene family: a standard nomenclature," Immunity, vol. 28, no. 3, pp. 285-287, 2008.

[137] F. Martinon, K. Burns, and J. Tschopp, “The Inflammasome: a molecular platform triggering activation of inflammatory caspases and processing of proIL- $\beta$," Molecular Cell, vol. 10, no. 2, pp. 417-426, 2002.

[138] I. C. Koo, C. Wang, S. Raghavan, J. H. Morisaki, J. S. Cox, and E. J. Brown, "ESX-1-dependent cytolysis in lysosome secretion and inflammasome activation during mycobacterial infection," Cellular Microbiology, vol. 10, no. 9, pp. 18661878, 2008.
[139] S. S. Master, S. K. Rampini, A. S. Davis et al., "Mycobacterium tuberculosis prevents inflammasome activation," Cell Host and Microbe, vol. 3, no. 4, pp. 224-232, 2008.

[140] B. B. Mishra, P. Moura-Alves, A. Sonawane et al., "Mycobacterium tuberculosis protein ESAT-6 is a potent activator of the NLRP3/ASC inflammasome," Cellular Microbiology, vol. 12, no. 8, pp. 1046-1063, 2010.

[141] J. Chan, Y. Xing, R. S. Magliozzo, and B. R. Bloom, "Killing of virulent Mycobacterium tuberculosis by reactive nitrogen intermediates produced by activated murine macrophages," Journal of Experimental Medicine, vol. 175, no. 4, pp. 11111122, 1992.

[142] L. A. H. Van Pinxteren, J. P. Cassidy, B. H. C. Smedegaard, E. M. Agger, and P. Andersen, "Control of latent Mycobacterium tuberculosis infection is dependent on CD8 T cells," European Journal of Immunology, vol. 30, no. 12, pp. 3689-3698, 2000.

[143] T. Ulrichs and S. H. E. Kaufmann, "New insights into the function of granulomas in human tuberculosis," Journal of Pathology, vol. 208, no. 2, pp. 261-269, 2006.

[144] I. Sugawara, H. Yamada, H. Kaneko, S. Mizuno, K. Takeda, and S. Akira, "Role of interleukin-18 (IL-18) in mycobacterial infection in IL-18- gene-disrupted mice," Infection and Immunity, vol. 67, no. 5, pp. 2585-2589, 1999.

[145] I. Sugawara, H. Yamada, S. Hua, and S. Mizuno, "Role of interleukin (IL)-1 type 1 receptor in mycobacterial infection," Microbiology and Immunology, vol. 45, no. 11, pp. 743-750, 2001.

[146] N. P. Juffermans, S. Florquin, L. Camoglio et al., "Interleukin1 signaling is essential for host defense during murine pulmonary tuberculosis," Journal of Infectious Diseases, vol. 182, no. 3, pp. 902-908, 2000.

[147] K. D. Mayer-Barber, D. L. Barber, K. Shenderov et al., "Cutting edge: caspase- 1 independent IL- $1 \beta$ production is critical for host resistance to Mycobacterium tuberculosis and does not require TLR signaling in vivo," Journal of Immunology, vol. 184, no. 7, pp. 3326-3330, 2010.

[148] E. McElvania Tekippe, I. C. Allen, P. D. Hulseberg et al., "Granuloma formation and host defense in chronic Mycobacterium tuberculosis infection requires PYCARD/ASC but not NLRP3 or caspase-1," PloS one, vol. 5, no. 8, p. e12320, 2010. 


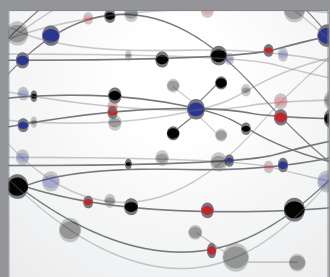

The Scientific World Journal
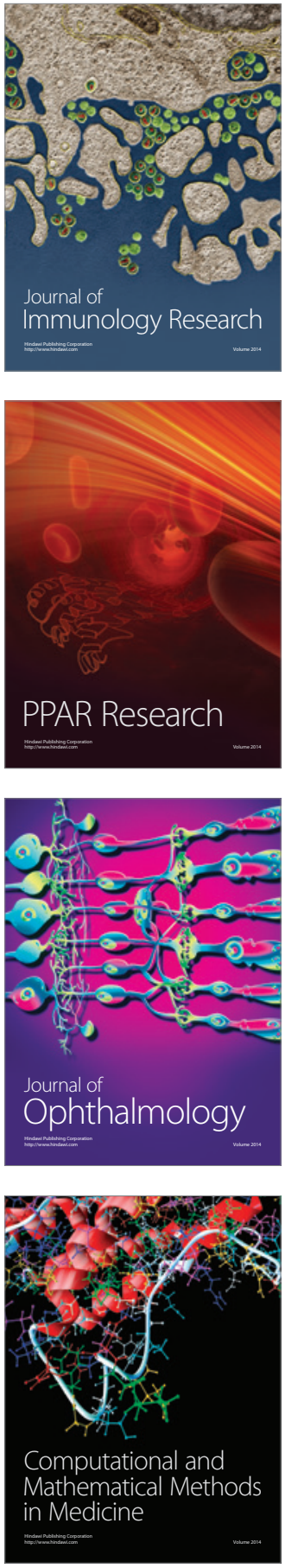

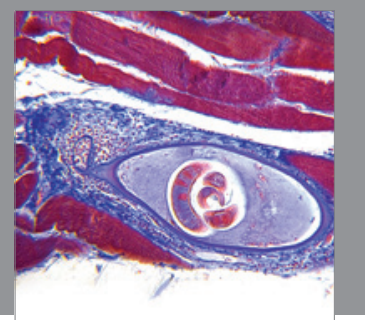

Gastroenterology

Research and Practice
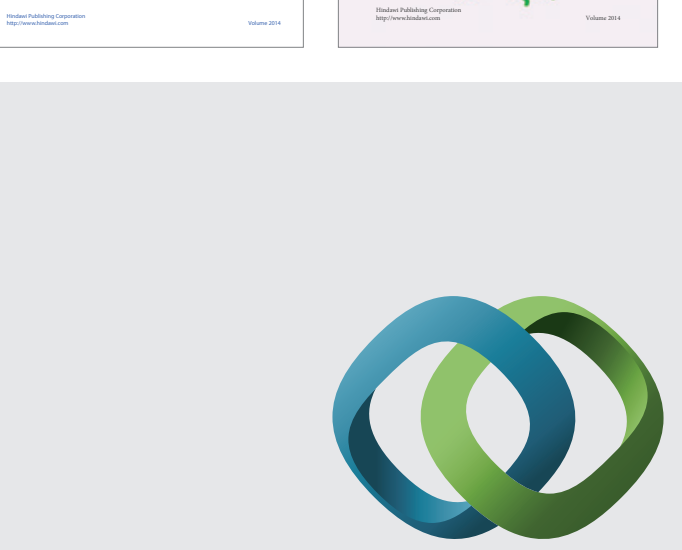

\section{Hindawi}

Submit your manuscripts at

http://www.hindawi.com
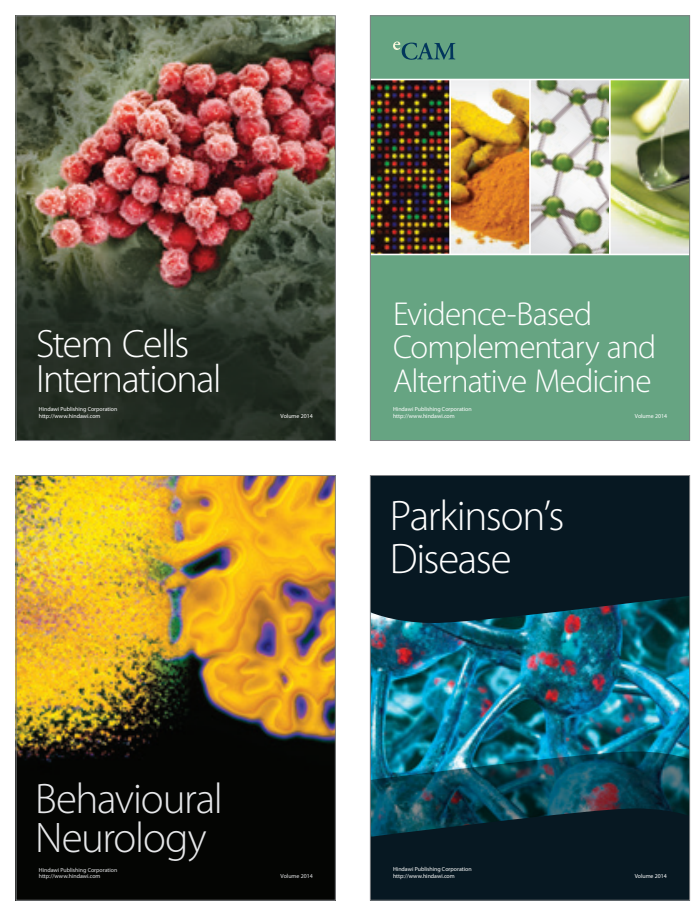

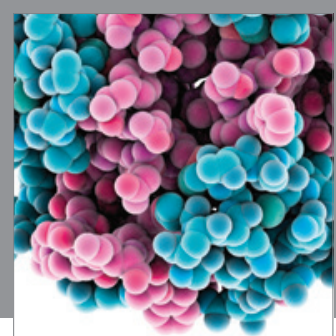

Journal of
Diabetes Research

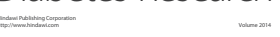

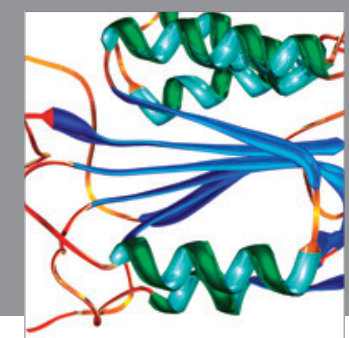

Disease Markers
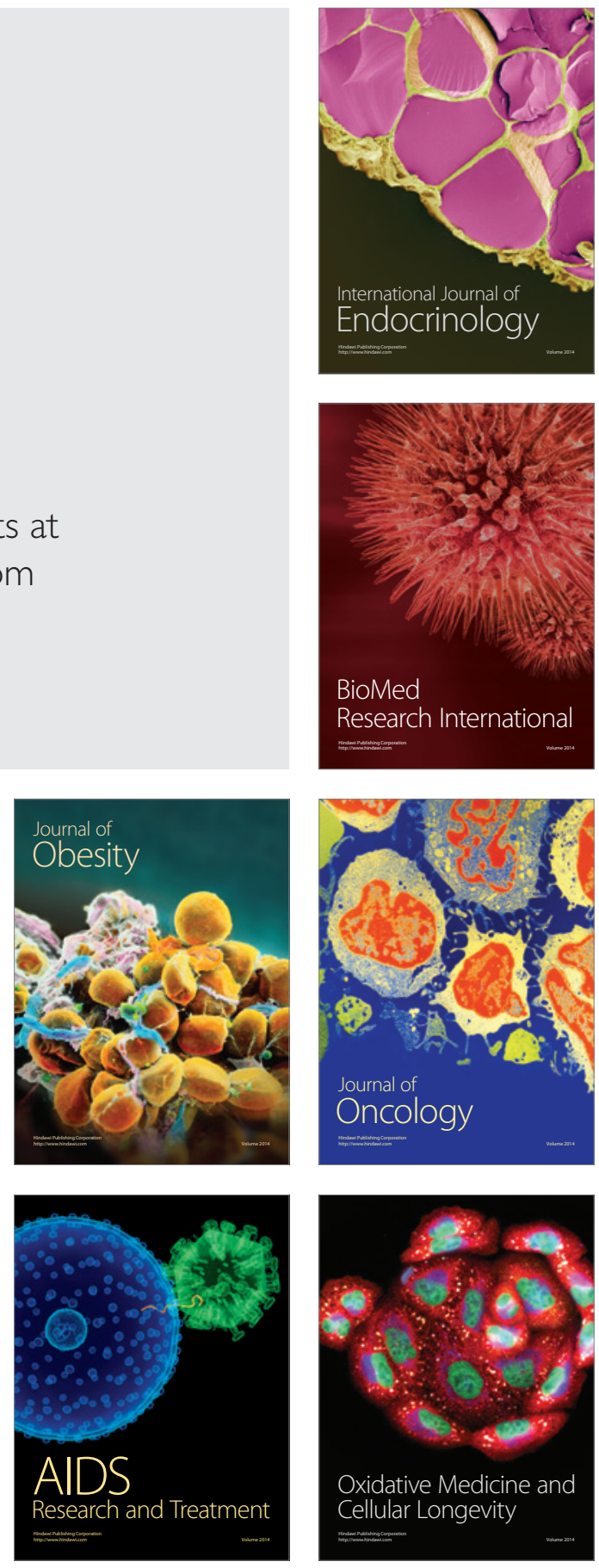